\title{
Farmer groups and inorganic fertiliser use among smallholders in rural South Africa
}

AUTHORS:

Sikhulumile Sinyolo

Maxwell Mudhara ${ }^{2}$

\section{AFFILIATIONS:}

${ }^{1}$ Economic Performance and Development, Human Sciences Research Council, Pretoria,

South Africa

2Discipline of Agricultural Economics, University of KwaZulu-Natal, Pietermaritzburg, South Africa

\section{CORRESPONDENCE TO: \\ Sikhulumile Sinyolo}

\section{EMAIL:}

sksinyolo@gmail.com

\section{DATES:}

Received: 20 Mar. 2017

Revised: 09 Jan. 2018

Accepted: 15 Jan. 2018

Published: 30 May 2018

\section{KEYWORDS:}

collective action; smallholder farming; propensity score matching; technology adoption KwaZulu-Natal

\section{HOW TO CITE:}

Sinyolo S, Mudhara M. Farmer groups and inorganic fertiliser use among smallholders in rural South Africa. S Afr J Sci. 2018;114(5/6), Art. \#2017-0083, 9 pages. http://dx.doi.org/10.17159/ sajs.2018/20170083

\section{ARTICLE INCLUDES: \\ $\times$ Supplementary material \\ $\times$ Data set}

\section{FUNDING:}

None

(C) 2018. The Author(s). Published under a Creative Commons Attribution Licence.
Smallholder farmers in developing countries are characterised by low uptake of improved farm inputs and weak links to markets. Among other reasons, the high transaction costs that these smallholder farmers incur, as a result of their location in remote areas, inadequate information and missing credit markets, inhibit them from participating in both input and output markets. Organising farmers into groups has been suggested as a potential mechanism for reducing transaction costs. Accordingly, farmer groups have been preferred channels for smallholder farmer support in South Africa, both by the government and donors. However, the impact of these groups on smallholder outcomes such as technology adoption is largely unknown. We investigated the extent to which membership in farmer groups influences the use of improved farm inputs such as inorganic fertiliser among smallholder farmers in South Africa. A sample of 984 households was analysed using the propensity score matching method. Group membership was found to play a positive role in inorganic fertiliser use with a 14\% higher chance of inorganic fertiliser use among group members. Among fertiliser users, group members used $170 \mathrm{~kg}$ more inorganic fertiliser than did non-members. Further analysis indicated that the effect of group membership on inorganic fertiliser use was heterogeneous among group members. The results suggest that farmer groups play a positive role in the use of improved farm inputs in South Africa. For greater effectiveness of group membership, policymakers should target the less educated, increase the assets of the poor and improve access to extension and information.

\section{Significance:}

- The impact of farmer groups on smallholder outcomes such as technology adoption is largely unknown.

- $\quad$ Farmer groups were found to play a positive role in the adoption of agricultural technologies such as inorganic fertilisers.

- Effect of group membership on inorganic fertiliser adoption was heterogeneous among group members.

- Variables that should be targeted for greater effectiveness of collective action were identified.

\section{Introduction}

Smallholder farming plays an important role in the livelihoods of the poor in the developing world, in general, and in sub-Saharan Africa in particular. However, smallholder farmers face several constraints that have limited the effectiveness of their farming activities in alleviating the rural poverty and food insecurity challenges. They are often located in remote areas with poor infrastructure, inadequate information and imperfect or missing credit markets, which results in higher transaction costs. ${ }^{1-5}$ The higher transaction costs reduce their incentives for participation in both agricultural output and input markets. Moreover, these farmers are poorly endowed with assets and lack adequate access to government support services such as extension and training, which are important in alleviating the effects of high transaction costs. ${ }^{6-8}$

Thus, the smallholder farmers in sub-Saharan Africa are characterised by low uptake of improved farm inputs and weak links to output markets. ${ }^{9-12}$ For example, whereas the average intensity of inorganic fertiliser use in Latin America and Asia is about $100 \mathrm{~kg} / \mathrm{ha}$, it is below $10 \mathrm{~kg} / \mathrm{ha}$ in sub-Saharan Africa. ${ }^{9,13,14}$ In South Africa, the average inorganic fertiliser application rates of smallholders are significantly below the recommended levels for the respective agro-ecological regions in the country, and are too low and ineffective to sustain crop and soil fertility. ${ }^{15,16}$ There is therefore a need for mechanisms to address the challenges that smallholders face to enhance their market participation as well as increase their modern technology adoption rates to ensure that they benefit from these technological advancements.

Several studies have indicated that organising farmers into groups can play a significant role in reducing transaction costs and increasing farmers' market participation and input use. ${ }^{2,4,5,7,8,17}$ Farmer groups can provide a variety of services that are key for market access, input use and improved welfare. ${ }^{4}$ For instance, buying inputs or selling outputs collectively results in economies of scale, which reduces transportation and transaction costs and increases bargaining power (resulting in favourable prices). ${ }^{17}$ Governments and development agencies all over the developing world are placing considerable emphasis on using collective action as a means of effectively linking smallholders with input and output markets., , 18-22 $^{2}$

The South African government has also been actively promoting collective action through groups among the smallholder farmers. ${ }^{15,23,24}$ For example, Output 5 of Outcome 7 of the government's outcomes approach aimed to, among other targets, have at least $30 \%$ of smallholder farmers organised into producers' associations or marketing co-operatives by $2014 .{ }^{24}$ These farmer groups are expected to give collective power in negotiations for inputs and marketing, thus enhancing the institutional environment for poverty reduction and sustainable and inclusive growth in the rural areas. ${ }^{24}$ Farmer groups are also the preferred channel through which most nongovernmental organisations (NGOs) and donors reach and support the poor with their food security and poverty 
reduction interventions in the rural areas. Hence, several farmer groups and cooperatives have been formed in the smallholder sector. While some of the groups focus on one purpose (e.g. marketing), most of these groups are multi-purpose: helping the farmers access information, secure inputs as well as sell their produce. ${ }^{15}$

Membership in these groups enables pooling of resources, sharing of information as well as collective bargaining, thereby increasing the participation of the smallholder farmers in both the input and output markets. The government as well as NGOs often give free and/or subsidised inputs, credit or training through these farmer groups. While organising farmers into groups may make service provision by government and NGOs easier in many respects, its impact on the farmers themselves is mixed. ${ }^{4,25}$ Literature is available on the impact of farmer groups in the output markets, and the results, although somewhat mixed, suggest a positive role of collective action on output market participation. ${ }^{2,21,26-28}$ However, few studies, such as Abebaw and Haile have focused on the groups' potential role in improving the adoption of modern technologies. While studies such as Abebaw and Haile ${ }^{7}$ are relevant, these studies should not be generalised because technology adoption is context specific. ${ }^{29,30}$

In this study, we investigated the extent to which membership in farmer groups influences inorganic fertiliser use among smallholder farmers in the KwaZulu-Natal (KZN) Province of South Africa, using the propensity score matching technique. This study contributes to the literature in three ways. First, while previous technology adoption studies either failed to include group membership in their models, or did not control for its potential endogeneity in the models, as noted in Abebaw and Haile $^{7}$, we controlled for potential endogeneity issues using propensity score matching. Propensity score matching pairs group members and non-members who have similar observable characteristics to control for endogeneity problems that arise from observable variables. Second, we did not assume that group membership has homogenous effects, but also investigated the heterogeneous effects of group membership on fertiliser use. That is, we asked: who is likely to benefit more from being a member of a group? This aspect is important for evidence-based policy and for better targeting of interventions meant to increase modern technology use among smallholder farmers.

Thirdly, we focused on smallholder farmers in KZN. To our knowledge, few studies on this subject, if any, have been done in South Africa in general and KZN in particular. We focused on KZN because smallholder farming is very important in the province, as most rural-based people are employed or self-employed in this sector. According to StatsSA ${ }^{31}$, more than $28 \%$ of the households in KZN are directly involved in agriculture. The high unemployment rate (33\%) in the province, especially among the youth $(42 \%)$, has resulted in a number of household members who fail to secure employment in urban areas, returning to rural areas to engage in smallholder farming, among other economic activities. ${ }^{31}$ The other motivation for selecting KZN as the study area was that, even though it has a huge potential in agriculture owing to good, reliable rainfall (more than $1000 \mathrm{~mm}$ a year), smallholder farmers have failed to tap into this potential because of, among other reasons, their use of rudimentary and out-of-date farming methods. ${ }^{32}$ According to KZN-DAE ${ }^{32}$, the agricultural output could be increased significantly if modern farming practices were adopted and the natural resources optimally managed for agriculture.

\section{Research methodology}

\section{Theoretical framework and selection of variables}

Group membership was analysed as a choice problem within a random utility framework ${ }^{33}$, following previous literature ${ }^{2,7,17,34}$. According to the random utility theory, a farmer decides to be a group member if the expected utility from group membership $\left(U_{i}^{M}\right)$ is greater than that of non-membership $\left(U_{j}\right)$, i.e. a farmer chooses group membership if the expected net utility $\left(U_{i}^{M}-U_{i}^{N}\right)$ is greater than zero. The unobserved net utility can be expressed as a function of observable elements in the following latent variable model:

$U_{i}^{*}=\beta Z_{i}+\varepsilon_{i}, U_{i}=1$ if $U_{i}^{*}>0$

Equation 1 where $U_{i}$ is a binary indicator variable that equals 1 for household $i$ in case of group membership and 0 otherwise; $\beta$ is a vector of parameters to be estimated; Zi is a vector of household and farm characteristics; and $\varepsilon_{\mathrm{i}}$ is an error term.

Group membership is associated with potential costs (membership fees, time, etc.) and benefits (better access to information, inputs, collective bargaining, etc.), which may be perceived differently by different households., ${ }^{2,17}$ Individual comparative advantage plays an important role in the choice of whether or not to join a group. ${ }^{2}$ Farmers incur different transaction costs because of heterogeneities in household resource endowments and access to information, which results in different market behaviour. ${ }^{1,235,36}$ The selection of variables into the group membership decision model was based on previous literature. 2,7,26,27,37 Table 1 presents the variables that were considered. These variables include personal details of household head and household characteristics (age, gender, education level, employment status, etc.), wealth and asset endowment (land size, livestock size, income, asset values, etc.), access to support services (extension, credit, training, information, etc.), infrastructural and/institutional support (irrigation, distance to the nearest all-weather road, location/district, etc.).

Table 1: Variables and their descriptions

\begin{tabular}{|c|c|}
\hline Variable code & Variable name and description \\
\hline \multicolumn{2}{|l|}{ Outcome variable } \\
\hline FERTUSE & Fertiliser adoption ( $1=$ adopter, $0=$ non-adopter) \\
\hline FERTKG & Amount of fertiliser used (kg) \\
\hline \multicolumn{2}{|l|}{ Treatment variable } \\
\hline GROUP & Farmer group membership ( $1=$ yes, $0=$ no $)$ \\
\hline \multicolumn{2}{|c|}{ Independent variable } \\
\hline AGE & Age (years) \\
\hline GENDER & Gender $(1=$ male, $0=$ female $)$ \\
\hline MARRIED & Marital status ( $1=$ married, $0=$ unmarried $)$ \\
\hline EDUCAT & Education level (years) \\
\hline HHSIZE & Household size (number of people) \\
\hline LAND & Land size (ha) \\
\hline TLU & Livestock size (TLUs) \\
\hline ASSETS & Value of household assets (ZAR) \\
\hline TOTINC & Annual total household income (ZAR) \\
\hline EXTENSION & Access to extension $(1=y e s, 0=$ no $)$ \\
\hline INFORM & Number of information sources \\
\hline CREDIT & Access to credit $(1=$ yes, $0=$ no) \\
\hline TRAINING & Access to agricultural training ( $1=$ yes, $0=$ no) \\
\hline ROADDIST & Distance to the nearest all-weather road $(\mathrm{km})$ \\
\hline FARMEXP & Farming experience (years) \\
\hline IRRIGAT & $\begin{array}{l}\text { Access to water for irrigation purposes }(1=y e s \text {, } \\
0=\text { no) }\end{array}$ \\
\hline EMPLOYED & Off-farm employment ( $1=$ yes, $0=$ no) \\
\hline BUSINESS & $\begin{array}{l}\text { Ownership of small non-farm business }(1=y e s \text {, } \\
0=\text { no) }\end{array}$ \\
\hline HGWALA & District 1 ( $1=$ Harry Gwala, $0=$ otherwise) \\
\hline UMZINYAT & District 2 ( 1 =Umzinyathi, 0 = otherwise) \\
\hline UTHUKELA & District 3 ( 1 =Uthukela, 0 = otherwise) \\
\hline UMKHANYA & District 4 ( $1=$ Umkhanyakude, $0=$ otherwise) \\
\hline
\end{tabular}


Personal characteristics of the household heads such as age, gender, marital status and education level determine group membership by influencing the opportunity cost of time and attitudes towards collective action. $2,7,38$ The outcome variables considered were the decision to use inorganic fertilisers and the amount used. The amount of fertiliser used applies to the adopters only, as the non-adopters do not have these figures.

\section{Data}

Data were collected from 984 farming households drawn from four districts in KZN. The survey was conducted using a multistage sampling technique. First, 4 districts were purposely chosen out of the 11 districts in the province. The four districts selected were Harry Gwala, Umzinyathi, Umkhanyakude and Uthukela. These districts have a significant number of rural households engaged in farming activities. Second, one local municipality was randomly selected for each district: the Ubuhlebezwe local municipality in the Harry Gwala district; the Msinga local municipality in the Umzinyathi district; the Jozini local municipality in the Umkhanyakude district; and the Imbabazane local municipality in the Uthukela district.

Third, a total of 984 rural households were randomly selected from the four local municipalities. The list of farming households was obtained from the respective local offices of KZN's Department of Agriculture. No stratification was done according to group membership (or any other variable), giving an equal chance for both group members and nonmembers to be included. The total sample comprised 411 households from Ubuhlebezwe, 239 from Msinga, 143 from Jozini and 191 from Imbabazane. The number of households sampled was not proportional to the population sizes of the respective local municipalities, but was proportional to the number of farming households, as received from the local Department of Agriculture.

The data were collected during the months of October and November 2014 using a structured questionnaire. The questionnaire was administered by experienced enumerators who spoke the local IsiZulu language. These enumerators were trained before the survey. Questionnaire pre-testing, involving 15 rural households, was also done. The ambiguities or difficulties with regard to question wording were noted and remedied during questionnaire pre-testing. The questionnaire included household demographics and socio-economic characteristics; income and wealth endowment; institutional support services; membership in farmer organisations; and inorganic fertiliser use. The data on the use of chemical fertilisers refer to agricultural season prior to the survey, i.e. the $2013 / 2014$ season. All procedures performed in the study were approved by the Human and Social Sciences Research Ethics Committee of the University of KwaZulu-Natal (reference number HSS/0027/015D). Informed consent of the study subjects was obtained and the principles of the 1964 Helsinki declaration were adhered to.

\section{Propensity score matching}

To investigate the impact of group membership on inorganic fertiliser adoption, we used the propensity score matching (PSM) method. This non-experimental approach is adopted because group membership is non-random, as an individual household decides to join a group voluntarily. As such, households which are group members might systematically differ from non-members in several socio-economic observable characteristics that may have a direct effect on inorganic fertiliser use. To the extent that group and non-members are different, simply computing the difference between the mean values of the outcome variable of interest of the two categories gives biased results. PSM identifies non-members of groups that are similar to members in their observable characteristics, and comparisons are made in the region of common support. Compared to estimates based on full samples, the impact estimates based on matched samples are less biased and more reliable. ${ }^{39,40}$

To apply PSM in this study, we assumed that our outcome of interest is the amount of inorganic fertiliser used. Further, we assumed that the amount of inorganic fertiliser used by group member $i$ is $Y_{1}$. The amount of inorganic fertiliser used by a non-member is then assumed to be
$Y_{0 .}$ G. denotes group membership by household $i$, which can take two values: namely $G_{i}=1$ if the household is a group member and $G_{i}=0$ if the household is a non-member. Our interest was to evaluate the impact of group membership on those households that are group members. The focus is on estimating the average treatment effect on the treated (ATT), the expected treatment effect over the sample of group members, which is estimated as follows:

ATT $=E\left[\Delta_{\mathrm{i}} \mathrm{I} \mathrm{G}_{\mathrm{i}}=1\right]=\mathrm{E}\left[\mathrm{Y}_{1 \mathrm{i}, \mathrm{t}} \mid \mathrm{G}_{\mathrm{i}}=1\right]-\mathrm{E}\left[\mathrm{Y}_{0, \mathrm{t}} \mid \mathrm{G}_{\mathrm{i}}=1\right]$

Equation 2

where $E\left[\Delta \mid G_{i}=1\right]$ is the expected treatment effect; $E\left[Y_{i 1} \mid G_{i}=1\right]$ is the amount of inorganic fertiliser used by the group members; and $E\left[Y_{i 0} \mid G_{i}=1\right]$ is the amount of inorganic fertiliser that would have been used by group members had they not been group members. The ATT captures the change in the amount of fertiliser (outcome) realised by households which are group members subject to their group membership status.

The fundamental evaluation problem is that of missing data. ${ }^{41}$ This is because the amount of inorganic fertiliser for the group members, had they not been group members, cannot be observed. Similarly, the amount of inorganic fertiliser used by the non-member households, had they been group members, cannot be observed. In other words, the treatment indicator takes either one or zero, but not both. The PSM procedure was used to generate the missing data. ${ }^{42-46} \mathrm{PSM}$ can estimate the causal group membership impact as the difference between the amount of fertiliser used for the group members and what would have been the case if these members had not joined groups. Estimating the propensity score, which is simply the probability that a household is a group member, is a crucial step in using matching as an evaluation strategy. The logit model was used to generate the propensity scores as follows:

$p\left(Z_{\mathrm{i}}\right)=\operatorname{Prob}\left(G_{\mathrm{i}}=1 \mid \mathrm{Z}_{\mathrm{i}}\right)$

Equation 3

where $p\left(Z_{i}\right)$ is the propensity score; $G_{i}$ is group membership; and $Z_{i}$ are the observed household socio-economic characteristics affecting group membership.

According to Becker and Ichino ${ }^{47}$, an estimate of the propensity score is not enough to estimate the average treatment effect on the treated (ATT), because the probability of observing two units with exactly the same value of the propensity score is, in principle, zero. Various matching algorithms have been proposed in the literature to determine the region of common support. The most widely used are the nearestneighbour matching, radius matching, Kernel matching and stratification matching. ${ }^{41,47-49}$

A matching estimator is considered good if, on the one hand, it does not eliminate too many of the original observations from the final analysis, while, on the other hand, it yields statistically equal covariate means for households in the treatment and control groups. ${ }^{7,50}$ The nearest-neighbour matching and Kernel matching are reported in this study. The nearest neighbour was chosen because it is generally used in practice because of its ease of implementation, while Kernel matching is a recently developed technique that is gaining popularity in non-experimental literature. ${ }^{41}$ The balancing property was selected in estimating the propensity scores. The use of the balancing property ensures that a comparison group is constructed with observable characteristics distributed equivalently across quintiles in both the treatment and comparison groups. ${ }^{41}$

In constructing the matching estimates, the common support was imposed. The treatment observations with weak common support were dropped, as inferences can be made about causality only in the area of common support. ${ }^{48}$ All the standard errors were bootstrapped with 1000 repetitions, as suggested by Smith and Todd ${ }^{41}$. The sensitivity of the estimated average adoption effects to hidden bias was tested using the Rosenbaum bounds sensitivity test. ${ }^{51}$ This test indicates how strongly an unobservable variable must influence the selection process to undermine or reverse the findings based on matching on observables. ${ }^{51-53}$ Previous 
studies on group membership impacts such as Abebaw and Haile, Cunguara and Darnhofer ${ }^{54}$ and Tilahun et al. ${ }^{34}$ have used the same approach to test for hidden bias in impact estimates. We focused on positive self-selection in search for evidence for overestimation of ATT, even though the Rosenbaum procedure provides bounds to both positive and negative self-selection.

The estimation of ATT assumes a homogenous treatment effect among the group members. However, as explained in previous studies, $7,40,54,55$ the treatment effects are not the same for all the different socioeconomic groups within the same treatment group. To investigate the extent to which the treatment effect on fertiliser adoption varies within group members, ordinary least squares regression of the householdlevel treatment effect on some background characteristics of the group members was estimated.

\section{Results and discussion}

\section{Descriptive statistics}

Table 2 presents the descriptive statistics of the interviewed households according to group membership status. The table shows that 414 of the sampled households were group members, representing over $42 \%$ of the sample. Discussion with the group members indicated that most of these groups have not yet been formally registered, although there is a government effort to ensure that these groups are formally registered as cooperatives. The group members indicated that the groups render several services to their members, such as dissemination of price or market information, collective purchasing of input, output market access, credit and savings, training and information/experience sharing. Some of the benefits of group membership, according to the farmers, is that groups make it easier to access government or NGO support, as these bodies prefer to disseminate extension information, inputs and other forms of support to groups over individuals. The high proportion of smallholders who are members of farmer groups implies that the government's drive to ensure that at least $30 \%$ of smallholders are members of groups may have been achieved in the study area. However, the process of formal registration is ongoing.

Table 2 shows that group members were more educated, had bigger households and were wealthier (in terms of land, livestock, assets and income) than the non-members. Table 2 also suggests that group members have better access to support services such as extension, information and credit. The non-farm business owners and those with more farming experience were less likely to be group members. Most sampled households in Uthukela and Umkhanyakude districts were members of the various farmer groups.

Table 2 also shows that inorganic fertiliser use is significantly different between group members (59\%) and non-members (53\%). Among the fertiliser users, the table indicates that the group members applied nearly

Table 2: Descriptive statistics of sample households according to group membership status

\begin{tabular}{|c|c|c|c|c|}
\hline \multirow{2}{*}{ Variable } & \multicolumn{3}{|c|}{ Means } & \multirow{2}{*}{$\begin{array}{c}t \text {-test } \\
\left(X^{2} \text { tests) }\right.\end{array}$} \\
\hline & Pooled sample $(n=984)$ & Group members $(n=414)$ & Non-members $(n=570)$ & \\
\hline FERTUSE & 0.56 & 0.59 & 0.53 & $3.86^{\star \star}$ \\
\hline FERTKGa & 245.40 & 357.21 & 172.85 & $4.37^{\star \star \star *}$ \\
\hline AGE & 56.11 & 56.31 & 55.96 & 0.42 \\
\hline GENDER & 0.47 & 0.50 & 0.44 & $4.46^{\star *}$ \\
\hline EDUCAT & 4.67 & 4.95 & 4.47 & $1.78^{*}$ \\
\hline HHSIZE & 7.04 & 7.70 & 6.56 & $4.98^{\star \star \star}$ \\
\hline LAND & 1.93 & 2.50 & 1.52 & $3.44^{\star \star \star}$ \\
\hline TLU & 3.53 & 4.95 & 2.49 & $2.18^{* *}$ \\
\hline ASSETS & 82105.38 & 88178.31 & 77694.52 & $4.20^{\star \star \star}$ \\
\hline TOTINC & 46757.43 & 51581.08 & 43253.93 & $3.97^{\star \star \star}$ \\
\hline EXTENSION & 0.57 & 0.68 & 0.49 & $35.38^{\star * *}$ \\
\hline INFORM & 2.28 & 2.65 & 2.01 & $9.37^{\star \star \star}$ \\
\hline CREDIT & 0.36 & 0.40 & 0.32 & $6.79^{\star \star \star}$ \\
\hline TRAINING & 0.41 & 0.57 & 0.30 & 76.63 \\
\hline ROADDIST & 17.75 & 17.28 & 18.01 & -0.31 \\
\hline FARMEXP & 18.70 & 16.25 & 20.47 & $4.98 * \star \star$ \\
\hline IRRIGAT & 0.46 & 0.48 & 0.45 & 0.86 \\
\hline EMPLOYED & 0.20 & 0.19 & 0.21 & 0.22 \\
\hline BUSINESS & 0.08 & 0.11 & 0.06 & $5.97^{\star \star}$ \\
\hline HGWALA & 0.42 & 0.17 & 0.60 & 180.60 \\
\hline UMZINYAT & 0.24 & 0.26 & 0.23 & 0.94 \\
\hline UTHUKELA & 0.19 & 0.28 & 0.13 & $35.79^{\star \star \star}$ \\
\hline UMKHANYA & 0.15 & 0.29 & 0.04 & $120.20 * \star \star$ \\
\hline
\end{tabular}

aIndicates the 554 farmers who used inorganic fertilisers.

Significant at the $* 10 \%, * \star 5 \%$ or $* * * 1 \%$ level. 
double the fertiliser quantities applied by the non-members. The boxand-whisker plots in Figure 1 also show that group members used higher quantities of fertiliser than non-members, and that there were relatively higher variations in the fertiliser quantities used among group members than among non-group members. Figure 2 presents the plots showing the quantity of fertiliser used by farmers according to group status and district. Again, the figure shows higher levels of fertiliser use and variations among group members across all districts, with the exception of the Umzinyathi district. However, at this stage, the results should not be used to make inferences regarding the impacts of groups on improved agricultural technology adoption as confounding factors have not been controlled for, which is done through the econometric model later.

\section{Determinants of group membership and estimation of the propensity scores}

The logit model was estimated to investigate the factors associated with membership in farmer groups and compute the propensity scores.
The results are presented in Table 3. The estimated model fits the data reasonably well as the likelihood ratio $X^{2}$ is statistically significant at the $1 \%$ level and the model correctly predicts $80 \%$ of the sample observations. Most of the variables in Table 3 have the expected signs. The results indicate that group membership is significantly associated with a household's demographic and socio-economic characteristics as well as access to support services.

Table 3 shows that, consistent with previous literature ${ }^{2,7,27}$, age is associated with increasing chances of group membership. An additional year is associated with an increase of $0.4 \%$ in the likelihood of group membership. This implies that older farmers are more inclined towards working as groups while the younger prefer working as individuals. The reason is that older farmers would have developed more contacts and trust, and have more positive attitudes to group membership than younger farmers. The insignificant coefficient of gender suggests no bias in group membership. This is in contrast to past studies ${ }^{2,7}$ which have indicated that female-headed households are less likely to join groups

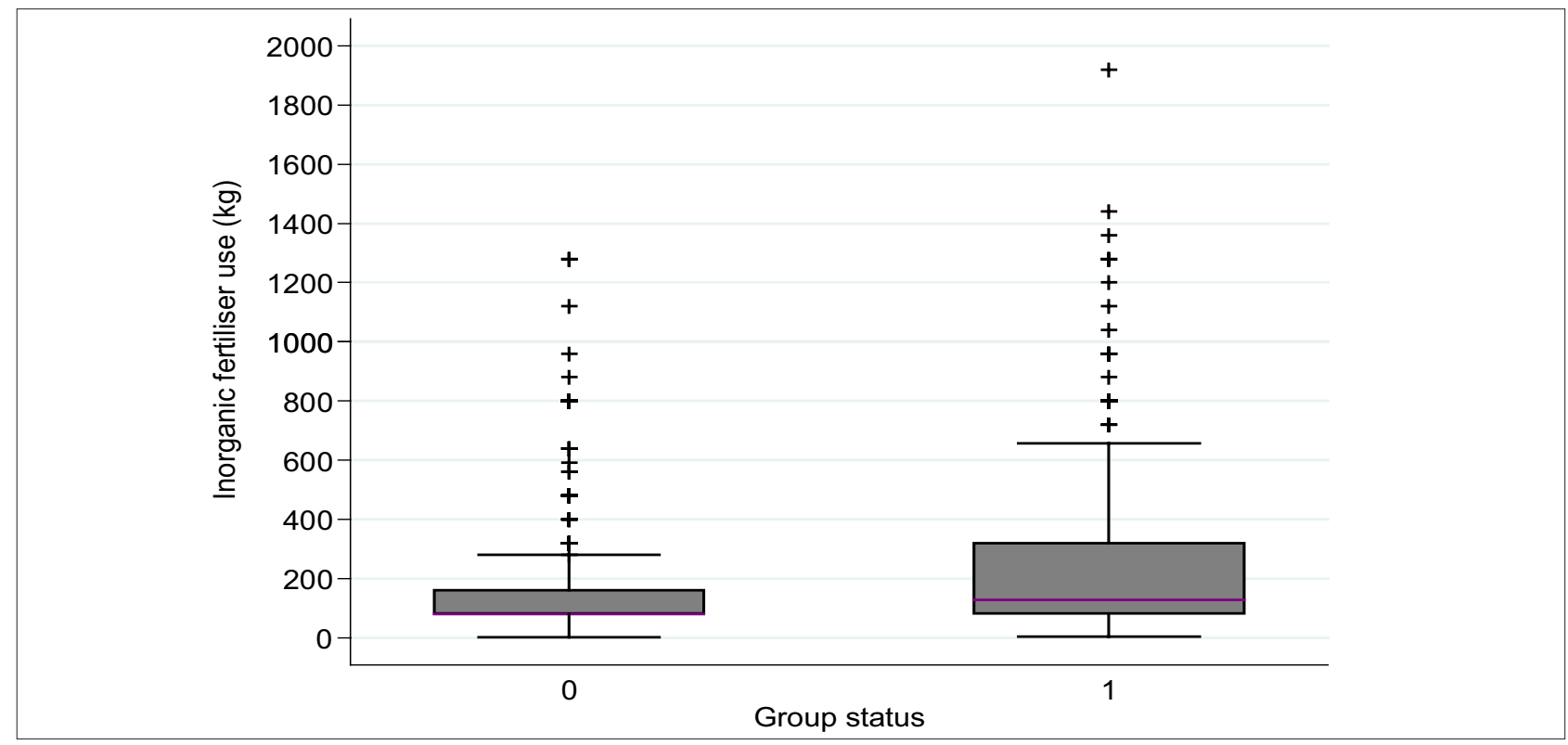

Figure 1: Box-and-whisker plots showing the quantity of fertiliser used by farmers according to group status: 0 indicates non-members and 1 indicates group members.

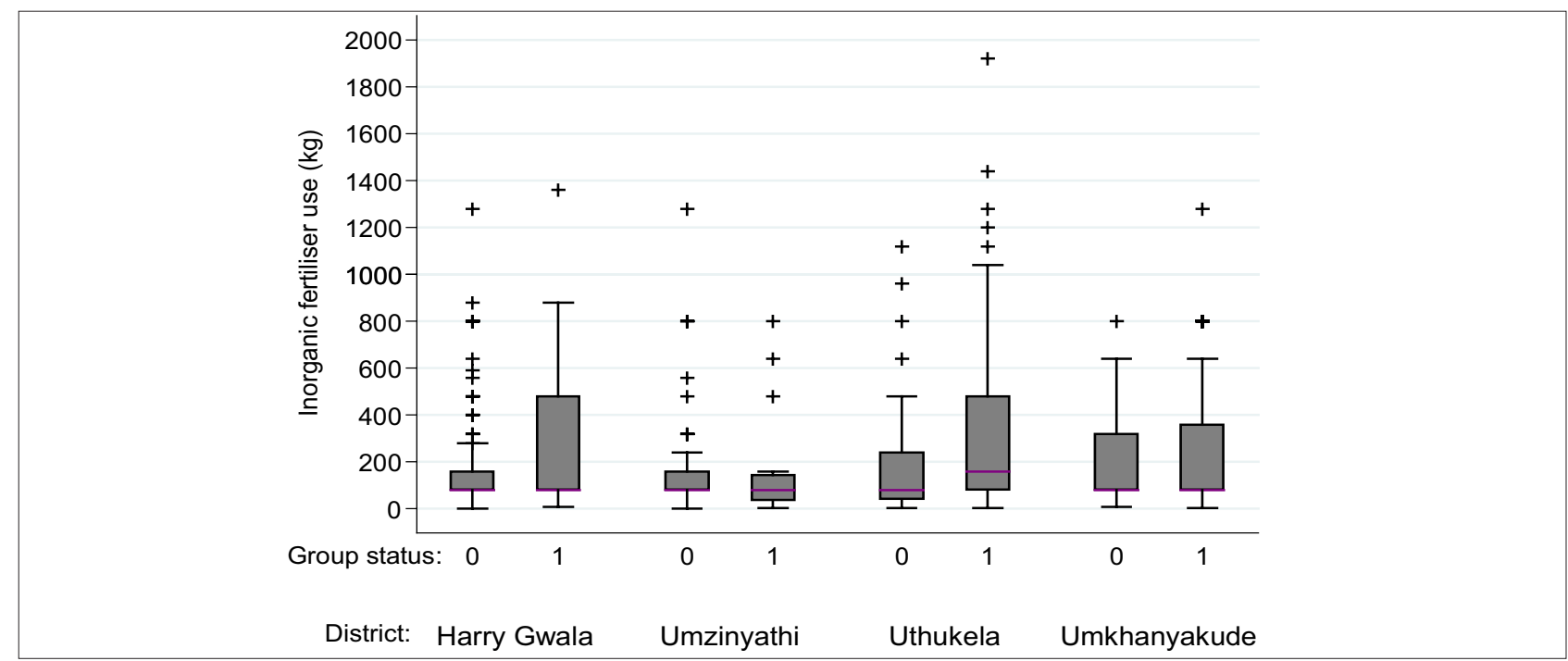

Figure 2: Box-and-whisker plots showing the quantity of fertiliser used by farmers according to district and group status: 0 indicates non-members and 1 indicates group members. 
Table 3: $\quad$ Factors determining farmer group membership: logit model results

\begin{tabular}{|c|c|c|c|c|}
\hline \multirow{2}{*}{ Variable } & \multicolumn{2}{|c|}{ Coefficients } & \multicolumn{2}{|c|}{ Marginal effects } \\
\hline & Value & Standard error & Value & Standard error \\
\hline AGE & $0.028^{* * *}$ & 0.008 & $0.004^{* * *}$ & 0.001 \\
\hline GENDER & -0.169 & 0.196 & -0.025 & 0.029 \\
\hline MARRIED & 0.269 & 0.184 & 0.040 & 0.028 \\
\hline HHSIZE & $0.045^{*}$ & 0.025 & $0.007^{\star}$ & 0.004 \\
\hline EDUCAT & $0.039 *$ & 0.022 & $0.006^{*}$ & 0.003 \\
\hline LAND & $0.364^{\star * *}$ & 0.085 & $0.055^{\star \star \star}$ & 0.012 \\
\hline TLU & -0.014 & 0.014 & -0.002 & 0.002 \\
\hline ASSETS $^{a}$ & $0.224^{*}$ & 0.126 & $0.033^{*}$ & 0.019 \\
\hline INCOMEa & $0.267^{*}$ & 0.149 & $0.040^{*}$ & 0.022 \\
\hline EXTENSION & $0.275^{\star \star}$ & 0.113 & $0.041^{\star \star}$ & 0.020 \\
\hline INFORM & $0.375^{\star * *}$ & 0.082 & $0.056^{\star * *}$ & 0.012 \\
\hline CREDIT & 0.204 & 0.176 & 0.030 & 0.026 \\
\hline TRAINING & $1.067^{\star \star \star}$ & 0.186 & $0.159 * * \star$ & 0.026 \\
\hline ROADDIST & $-0.010 * \star \star$ & 0.002 & $-0.002^{* * *}$ & 0.000 \\
\hline FARMEXP & $-0.026^{\star \star \star}$ & 0.007 & $-0.004^{\star \star \star}$ & 0.001 \\
\hline IRRIGAT & $0.115^{\star \star \star}$ & 0.016 & $0.017^{\star \star \star *}$ & 0.006 \\
\hline EMPLOYED & -0.208 & 0.243 & -0.031 & 0.036 \\
\hline BUSINESS & $0.921^{* * *}$ & 0.334 & $0.138^{\star \star \star}$ & 0.049 \\
\hline HGWALA & $-2.063^{\star \star \star}$ & 0.251 & $-0.308^{* * *}$ & 0.032 \\
\hline UTHUKELA & 0.025 & 0.269 & 0.004 & 0.040 \\
\hline UMKHANYA & $1.789 * \star \star$ & 0.352 & $0.267^{\star \star \star}$ & 0.049 \\
\hline CONSTANT & -8.119 & 1.922 & & \\
\hline Pseudo $\mathrm{R}^{2}$ & 0.332 & & & \\
\hline Likelihood ratio X² & $249.59 * * *$ & & & \\
\hline$\%$ predicted correctly & 0.80 & & & \\
\hline
\end{tabular}

${ }^{a}$ Assets and income values were logged.

Significant at the ${ }^{*} 10 \%, * \star 5 \%$ or $* * * 1 \%$ level.

than male-headed households because women face higher opportunity costs of time as a result of family responsibilities in addition to farming, reducing their incentives for group membership.

In line with studies such as Bernard and Spielman' $\mathrm{s}^{26}$ and Fischer and Qaim's ${ }^{2}$, the results indicate that household size is positively associated with group membership. Presumably, bigger households are more likely to participate in groups as a consequence of labour availability. Education, as a proxy of human capital, is also positively associated with participating in groups because the more educated are more likely to understand and interpret information better, which will result in them facing lower transaction costs and benefiting more from the group membership. Table 3 shows that increasing land size is positively correlated with membership in farmer groups. An increase of 1 ha is associated with an increased chance of group membership of $5.5 \%$. The net benefits of farmer group membership increase with increasing farm size, possibly because bigger farms signify increased agricultural production potential. As membership costs are usually fixed, farmers who produce more are likely to benefit more from the groups.
The same pattern also applies to other proxies of physical and financial capital such as asset values, income, irrigation access and ownership of non-farm micro-businesses. The positive relationship between physical as well as financial capital and group membership has been shown by several past empirical studies. ., $, 17,26,27,34,56$ The reason is that gains from participation in farmer groups are larger if a household owns complementary assets that enhance successful cooperation.

Access to support services such as extension, information services and training are associated with increased likelihood of group membership. Such services ease access to relevant information about the benefits of group membership. This is in line with previous literature. ${ }^{7,34}$ In South Africa, extension officers have been in the forefront of promoting group formation as the government prefers working with farmer groups. As such, extension officers are likely to influence the farmers they contact to form groups. Training also increases the chance of group membership by close to $16 \%$. A counterintuitive result in Table 3 is that distance to the nearest all-weather road has a significant and negative effect on group membership. One would have expected that farmers furthest from all- 
weather roads are more likely to join groups to alleviate transportation costs. A plausible explanation is that farmers in isolated areas do not have access to enough information about the benefits of group membership. This is unfortunate, as these are the farmers who would benefit the most from group membership (Table 7).

Farming experience is associated with decreasing chances of group membership. This suggests that experienced farmers would have developed enough individual capacity such that they prefer to work as individuals. The results also show location effects as district dummies, which were included to account for unobserved agro-climatic, institutional, market access and socioeconomic heterogeneities among the sample districts, were significant. In comparison to farmers located in the Umzinyathi district, farmers in Harry Gwala were less likely to participate in groups, while those in Umkhanyakude were more likely to participate. In summary, the logit results show that group participation was biased towards the educated, the relatively wealthier households and households with access to support services such as extension, training and information. Previous studies have also reported that the poor and uneducated tend to be excluded from membership in farmer groups. ${ }^{7,26}$

\section{Impact of group membership on inorganic fertiliser use}

The PSM method was employed to estimate the impact of group membership on the probability and level of inorganic fertiliser use. Table 4 shows the impact of group membership on fertiliser use probability. The impacts are estimated using both nearest-neighbour and kernel matching to ensure robustness.

Table 4: Impact of group membership on the probability of inorganic fertiliser use

\begin{tabular}{l|c|c|c|c}
\hline \hline \multirow{2}{*}{ Matching method } & \multicolumn{2}{|c|}{ Number of households } & \multirow{2}{*}{ ATT } & \multirow{2}{*}{$\boldsymbol{t}$-test } \\
\cline { 2 - 3 } & Treatment & Control & & \\
\hline Nearest neighbour & 414 & 158 & $0.140(0.063)$ & $2.210^{\star *}$ \\
\hline Kernel matching & 414 & 461 & $0.148(0.052)$ & $2.849 * \star \star$ \\
\hline
\end{tabular}

Significant at the ${ }^{* *} 5 \%$ or $* * * 1 \%$ level.

Table 4 shows that both the matching estimators yield similar results and that group membership has a positive and statistically significant effect on the probability of inorganic fertiliser use. The results indicate that the fertiliser use rate would be $14 \%$ lower if the farmers had not participated in farmer groups. The Rosenbaum bounds sensitivity analysis showed that the conclusion would change at a bounds statistic $(\Gamma)$ of 2.35. This implies that the results are only sensitive to a hidden bias that would more than double the odds of being a group member. Therefore, it is concluded that the results are not very sensitive to hidden bias, because it would require more than $130 \%$ of bias to reverse the conclusion.

Table 5 shows the impact of group membership on fertiliser use level. The table shows that the fertiliser use level would have been between $134 \mathrm{~kg}$ and $168 \mathrm{~kg}$ lower had farmers not joined farmer groups, indicating the positive role that farmer groups play in fertiliser use. Rosenbaum bounds test showed that the conclusion would change at $\Gamma=4.35$, implying that the results are not very sensitive to hidden bias because it would require more than $300 \%$ of bias to reverse the conclusion.

Table 5: Impact of farmer group membership on inorganic fertiliser use level

\begin{tabular}{l|c|c|c|c}
\hline \hline \multirow{2}{*}{ Matching method } & \multicolumn{2}{|c|}{ Number of households } & \multirow{2}{*}{ ATT } & \multirow{2}{*}{$t$-test } \\
\cline { 2 - 4 } & Treatment & Control & & \\
\hline Nearest neighbour & 218 & 88 & $167.41(52.95)$ & $3.161^{\star \star *}$ \\
\hline Kernel matching & 218 & 288 & $134.23(49.60)$ & $2.706^{\star \star *}$ \\
\hline
\end{tabular}

Significant at the $* * * 1 \%$ level.
To further evaluate the reliability of the above reported estimates, the balancing tests based on nearest neighbour were done and the results are presented in Table 6 . The table shows that, after matching, both group members and non-members have characteristics that are statistically similar. The test for equality of the two group means shows that there is no statistically significant difference between members and nonmembers after matching. This contrasts with the unmatched sample presented in Table 2 which indicated statistically significant differences in several covariates between the two groups. The standardised differences (\% bias) for the mean values of all the covariates between members and non-members are below $20 \%$, implying that the balancing requirement is adequately satisfied..$^{57}$

Table 6: Test of matching quality

\begin{tabular}{|c|c|c|c|c|c|}
\hline \multirow{2}{*}{ Variable } & \multicolumn{2}{|c|}{ Means } & \multirow{2}{*}{$\%$ Bias } & \multirow{2}{*}{$\begin{array}{c}\% \\
\text { Reduction } \\
\text { |bias }\end{array}$} & \multirow{2}{*}{$\begin{array}{c}p \text {-value of } \\
\text { equality of } \\
\text { mean }\end{array}$} \\
\hline & Members & Non-members & & & \\
\hline AGE & 56.31 & 55.60 & 5.4 & -99.8 & 0.42 \\
\hline EDUCAT & 4.95 & 5.14 & -2.4 & 68.3 & 0.50 \\
\hline HHSIZE & 7.70 & 7.71 & -4.6 & 59.6 & 0.97 \\
\hline LAND & 2.50 & 3.14 & -13.5 & 68.7 & 0.23 \\
\hline TLU & 4.95 & 4.18 & 4.1 & 68.8 & 0.57 \\
\hline ASSETS ${ }^{a}$ & 11.25 & 11.31 & -9 & 66 & 0.11 \\
\hline TOTINCa & 10.65 & 10.60 & 7.9 & 46 & 0.24 \\
\hline EXTENSION & 0.68 & 0.71 & -7.5 & 81 & 0.26 \\
\hline INFORM & 2.65 & 2.74 & -8.7 & 85.7 & 0.19 \\
\hline CREDIT & 0.40 & 0.36 & 9.1 & 46 & 0.20 \\
\hline TRAINING & 0.57 & 0.53 & 10.1 & 82.6 & 0.16 \\
\hline ROADDIST & 17.28 & 17.83 & -1.4 & 31.7 & 0.84 \\
\hline FARMEXP & 16.25 & 15.60 & 5 & 84.5 & 0.43 \\
\hline IRRIGAT & 0.48 & 0.44 & 7.3 & -21.6 & 0.30 \\
\hline EMPLOYED & 0.19 & 0.16 & 8.5 & -181.2 & 0.20 \\
\hline BUSINESS & 0.11 & 0.10 & 2.6 & 83.2 & 0.73 \\
\hline HGWALA & 0.17 & 0.17 & 0 & 100 & 1.00 \\
\hline UTHUKELA & 0.28 & 0.30 & -4.3 & 88.9 & 0.59 \\
\hline UMKHANYA & 0.29 & 0.29 & 0 & 100 & 1.00 \\
\hline
\end{tabular}

${ }^{\mathrm{a}}$ Assets and income values were logged.

\section{Impact heterogeneity}

To investigate the extent to which the treatment effect on fertiliser adoption differs among group members, the ordinary least squares regression was estimated and results are presented in Table 7 . The table shows that the impact of group membership is not the same among members. The results show that group membership increases inorganic fertiliser use more for the less educated than for those with more education. This is, as explained by Abebaw and Haile ${ }^{7}$, an important result as the poorly educated are less likely to adopt improved farm inputs as a result of their limited ability to understand and interpret new information on technologies. The impact is also larger for those with smaller household sizes and those households with more land and assets and fewer livestock. This result suggests that group membership benefits the richer more than it does the poorer. 
Table 7: Heterogeneous fertiliser use impacts among group members

\begin{tabular}{|c|c|c|}
\hline Variable & Coefficient & Standard error \\
\hline AGE & -0.001 & 0.002 \\
\hline GENDER & -0.039 & 0.053 \\
\hline MARRIED & -0.015 & 0.051 \\
\hline EDUCAT & $-0.012^{\star}$ & 0.006 \\
\hline HHSIZE & $-0.013^{* *}$ & 0.006 \\
\hline LAND & $0.025^{\star \star \star}$ & 0.008 \\
\hline TLU & $-0.004^{* *}$ & 0.002 \\
\hline ASSETS & $0.097^{\star \star \star}$ & 0.036 \\
\hline INCOME & 0.052 & 0.038 \\
\hline EXTENSION & $0.090^{*}$ & 0.055 \\
\hline INFORM & $0.043^{\star}$ & 0.022 \\
\hline CREDIT & 0.043 & 0.048 \\
\hline TRAINING & -0.067 & 0.048 \\
\hline ROADDIST & $0.002^{\star \star *}$ & 0.001 \\
\hline FARMEXP & $0.006^{\star \star \star}$ & 0.002 \\
\hline IRRIGAT & $0.156^{\star \star \star}$ & 0.047 \\
\hline EMPLOYED & -0.073 & 0.073 \\
\hline BUSINESS & $0.275^{\star \star \star}$ & 0.091 \\
\hline HGWALA & 0.047 & 0.076 \\
\hline UTHUKELA & $0.344^{\star \star \star}$ & 0.067 \\
\hline UMKHANYA & $-0.117^{\star}$ & 0.070 \\
\hline _CONS & -1.335 & 0.529 \\
\hline N & 414 & \\
\hline $\mathrm{F}$ & $6.16^{\star \star \star}$ & \\
\hline $\mathrm{R}^{2}$ & 0.248 & \\
\hline
\end{tabular}

Significant at the ${ }^{\star} 10 \%,{ }^{* \star} 5 \%$ or ${ }^{* *} * 1 \%$ level.

The farmers with access to extension and information would benefit more from farmer groups, as would farmers with access to irrigation. The results also suggest that the impact of farmer groups on inorganic fertiliser adoption is larger for experienced farmers, farmers located further from all-weather roads and owners of small, non-farm businesses. The greater impact of group membership for the farmers further away from all-weather roads suggests that groups contribute towards alleviating the transaction costs that these isolated farmers face. The fact that gender is not significant suggests that the impact of farmer groups on fertiliser adoption is the same for both male and female farmers, indicating no gender bias.

\section{Conclusions and policy implications}

The South African government has identified increased smallholder productivity and commercialisation as an integral part of the strategy for stimulating rural economic development and reducing poverty. The government has also invested considerable effort in organising smallholder farmers into groups to establish an enabling institutional environment for agricultural intensification and achieving sustainable, inclusive and better growth in the sector. Limited research has investigated the role of these farmer groups in improving the adoption of modern farm inputs. We investigated the impact of groups on the use of inorganic fertilisers using cross-sectional data from 984 households and the PSM technique.

The empirical results indicate that participation in farmer groups significantly and positively influences fertiliser use. Group membership improves the average fertiliser application rate by about $14 \%$, and the fertiliser use level by $134-168 \mathrm{~kg}$. The Rosenbaum bounds tests indicate the impact estimates obtained using the PSM approach were robust to hidden bias. The results also show greater group membership impact for the less educated, the wealthier (more land and assets), the irrigators, those with access to extension and information and those located further from all-weather roads. The findings suggest that the government's strategy of organising farmers into groups for improved smallholder production activities should continue, as groups raise the demand for improved farm inputs such as inorganic fertilisers. For greater effectiveness of membership of groups in improving modern technology adoption among smallholders, policymakers should target the less educated, increase the assets of the poor and improve access to extension and information.

\section{Authors' contributions}

S.S. was responsible for conceptualisation, methodology, data collection, data analysis, and writing the initial draft and revisions. M.M. was responsible for the methodology and critically reviewing the writing and revisions.

\section{References}

1. Key N, Sadoulet E, De Janvry A. Transactions costs and agricultural household supply response. Am J Agric Econ. 2000;82(2):245-259. https:// doi.org/10.1111/0002-9092.00022

2. Fischer E, Qaim M. Linking smallholders to markets: Determinants and impacts of farmer collective action in Kenya. World Dev. 2012;40(6):12551268. https://doi.org/10.1016/j.worlddev.2011.11.018

3. Godfray HCJ, Beddington JR, Crute IR, Haddad L, Lawrence D, Muir JF, et al. Food security: The challenge of feeding 9 billion people. Science. 2010;327(5967):812-818. https://doi.org/10.1126/science.1185383

4. Hellin J, Lundy M, Meijer M. Farmer organization, collective action and market access in Meso-America. Food Pol. 2009;34:16-22. https://doi. org/10.1016/j.foodpol.2008.10.003

5. Markelova H, Meinzen-Dick R, Hellin J, Dohrn S. Collective action for smallholder market access. Food Pol. 2009;34:1-7. https://doi.org/10.1016/j. foodpol.2008.10.001

6. Alene AD, Manyong VM, Omanya G, Mignouna HD, Bokanga M, Odhiambo G. Smallholder market participation under transactions costs: Maize supply and fertilizer demand in Kenya. Food Pol. 2008;33(4):318-328. https://doi. org/10.1016/j.foodpol.2007.12.001

7. Abebaw D, Haile MG. The impact of cooperatives on agricultural technology adoption: Empirical evidence from Ethiopia. Food Pol. 2013;38:82-91. http:// dx.doi.org/10.1016/j.foodpol.2012.10.003

8. Kruijssen F, Keizer M, Giuliani A. Collective action for small-scale producers of agricultural biodiversity products. Food Pol. 2009;34:46-52. https://doi. org/10.1016/j.foodpol.2008.10.008

9. African Union/New Partnership to Africa's Development (AU/NEPAD). The Abuja Declaration on Fertilizers for an African Green Revolution: Status of implementation at regional and national levels. Johannesburg: AU/NEPAD; 2011.

10. Diiro GM, Ker AP, Sam AG. The role of gender in fertiliser adoption in Uganda. Afr J Agric Resour Econ. 2015;10(2):117-130.

11. Yirga C, Hassan RM. Determinants of inorganic fertiliser use in the mixed crop-livestock farming systems of central highliands of Ethiopia. Afr Crop Sci J. 2013;21(3):669-681

12. Mwangi $M$, Kariuki S. Factors determining adoption of new agricultural technology by smallholder farmers in developing countries. J Econ Sustain Dev. 2015;6(5):208-216. 
13. Crawford EW, Jayne TS, Kelly VA. Alternative approaches for promoting fertilizer use in Africa. Agriculture and Rural Development Discussion Paper 22. Washington DC: The International Bank for Reconstruction and Development/The World Bank; 2006.

14. Morris M, Kelly VA, Kopicki RJ, Byerlee D. Fertilizer use in African agriculture: Lessons learned and good practice guidelines. Washington DC: World Bank; 2007. https://doi.org/10.1596/978-0-8213-6880-0

15. Department of Agriculture, Forestry and Fisheries (DAFF). A framework for the development of smallholder farmers through cooperatives development. Pretoria: DAFF; 2012

16. Mkhabela TS, Materechera SA. Factors influencing the utilization of cattle and chicken manure for soil fertility management by emergent farmers in the moist Midlands of KwaZulu-Natal Province, South Africa. Nutr Cycl Agroecosys. 2003;65:151-162. https://doi.org/10.1023/A:1022156210667

17. Fischer E, Qaim M. Smallholder farmers and collective action: What determines the intensity of participation? J Agric Econ. 2014;65(3):683-702. https://doi.org/10.1111/1477-9552.12060

18. Kaganzi E, Ferris S, Barham J, Abenakyo A, Sanginga P, Njuki J. Sustaining linkages to high value markets through collective action in Uganda. Food Pol. 2009;34:23-30. https://doi.org/10.1016/j.foodpol.2008.10.004

19. HLPE. Investing in smallholder agriculture for food security. HLPE report 6. A report by the High Level Panel of Experts on Food Security and Nutrition of the Committee on World Food Security. Rome: Food and Agricultural Organization (FA0); 2013.

20. IFAD. Promoting market access for the rural poor in order to achieve the Millennium Development Goals: Discussion paper [document on the Internet]. c2003 [cited 2014 May 27]. Available from: http://www.ifad.org/gbdocs/ gc/26/e/markets.pdf.

21. Narrod C, Roy D, Okello J, Avenda-o B, Rich K, Thorat A. Public-private partnerships and collective action in high value fruit and vegetable supply chains. Food Pol. 2009;34:8-15. https://doi.org/10.1016/j. foodpol.2008.10.005

22. Liverpool-Tasie LSO. Farmer groups and input access: When membership is not enough. Food Pol. 2014;46:37-49. https://doi.org/10.1016/j. foodpol.2014.01.006

23. Ortmann GF, King RP. Agricultural cooperatives I: History, theory and problems. Agrekon. 2007;46(1):18-46. https://doi.org/10.1080/03031853 .2007.9523760

24. RSA. Outcome 7: Vibrant, equitable and sustainable rural communities and food security for all [document on the Internet]. c2010 [cited $2016 \mathrm{Ju}$ 05]. Available from: http://www.gov.za/sites/www.gov.za/files/Delivery\%20 Agreement\%20-\%200utcome\%207_0.pdf

25. Cadzow H, Binns T. Are groups a good thing? Evaluating group associations among vegetable farmers in Freetown, Sierra Leone. Dev Pract. 2016;26(4):406-419. https://doi.org/10.1080/09614524.2016.1159662

26. Bernard T, Spielman DJ. Reaching the rural poor through rural producer organizations? A study of agricultural marketing cooperatives in Ethiopia. Food Pol. 2009;34(1):60-69. http://dx.doi.org/10.1016/j.foodpol.2008.08.001

27. Bernard T, Taffesse AS, Gabre-Madhin E. Impact of cooperatives on smallholders' commercialization behavior: Evidence from Ethiopia. Agric Econ. 2008;39(2):147-161. https://doi.org/10.1111/j.1574-0862.2008.00324.x

28. Shiferaw B, Obare G, Muricho G. Rural market imperfections and the role of institutions in collective action to improve markets for the poor Nat Resour Forum. 2008;32(1):25-38. https://doi.org/10.1111/j.14778947.2008.00167.x

29. Kafle $B$. Determinants of adoption of improved maize varieties in developing countries: A review. Int Res J Appl Basic Sci. 2010;1(1):1-7.

30. Ogada M, Mwabu G, Muchai D. Farm technology adoption in Kenya: A simultaneous estimation of inorganic fertilizer and improved maize variety adoption decisions. Agric Econ. 2014;2(1):1-18. https://doi.org/10.1186/ s40100-014-0012-3

31. Statistics South Africa (StatsSA). Census 2011 Municipal report - KwaZuluNatal [document on the Internet]. c2012 [cited 2015 Mar 09]. Available from: http://www.statssa.gov.za/Census2011/Products/KZN_Municipal_Report.pdf.

32. KwaZulu-Natal Department of Agriculture and Environmental Affairs (KZNDAE). Annual performance plan 2012/13. Pietermaritzburg: KZNDAE; 2012.

33. McFadden D. The measurement of urban travel demand. J Public Econ. 1974;3(4):303-328. http://dx.doi.org/10.1016/0047-2727(74)90003-6
34. Tilahun M, Maertens M, Deckers J, Muys B, Mathijs E. Impact of membership in frankincense cooperative firms on rural income and poverty in Tigray, Northern Ethiopia. For Policy Econ. 2016;62:95-108. http://dx.doi. org/10.1016/j.forpol.2015.08.009

35. Barrett CB. Smallholder market participation: Concepts and evidence from eastern and southern Africa. Food Pol. 2008:33:299-317. https://doi. org/10.1016/j.foodpol.2007.10.005

36. Boughton D, Mather D, Barrett CB, Benfica R, Abdula D, Tschirley D, et al. Market participation by rural households in a low-income country: An assetbased approach applied to Mozambique. Faith Econ. 2007;50:64-101.

37. Wollini M, Zeller M. Do farmers benefit from participating in speciality markets and cooperatives? The case of coffee marketing in Costa Rica. Agric Econ. 2007;37:243-248. https://doi.org/10.1111/j.1574-0862.2007.00270.x

38. Ostrom E. Collective action and the evolution of social norms. J Econ Perspect. 2000;14:137-158. https://doi.org/10.1257/jep.14.3.137

39. Rubin D, Thomas D. Combining propensity score matching with additional adjustments for prognostic covariates. J Am Stat Assoc. 2000;95:573-585. https://doi.org/10.1080/01621459.2000.10474233

40. Abebaw D, Fentie $Y$, Kassa B. The impact of a food security program on household food consumption in Northwestern Ethiopia: A matching estimator approach. Food Pol. 2010;35(4):286-293. http://dx.doi.org/10.1016/j. foodpol.2010.01.002

41. Smith J, Todd P. Does matching overcome LaLonde's critique of nonexperimental estimators? J Econom. 2005;125(1-2):303-353. https:// doi.org/10.1016/j.jeconom.2004.04.011

42. Baker JL. Evaluating the impact of development projects on poverty: A handbook for practitioners. Washington DC: World Bank; 2000. https://doi. org/10.1596/0-8213-4697-0

43. Jalan J, Ravallion M. Estimating the benefit incidence of an antipoverty program by propensity score matching. J Bus Econ Stat. 2003;21(1):19-30. https://doi.org/10.1198/073500102288618720

44. Ravallion M. Evaluating anti-poverty programs. In: Evenson RE, Schultz TP, editors. Handbook of agricultural economics. Amsterdam: Elsevier; 2008.

45. Blundell R, Costa-Dias M. Evaluation methods for non-experimental data. Fisc Stud. 2000;21(4):447-468. https://doi.org/10.1111/j.1475-5890.2000. tb00031.x

46. Khandker SR, Koolwal GB, Samad HA. Handbook on impact evaluation: Quantitative methods and practice. Washington DC: The World Bank; 2010.

47. Becker OS, Ichino A. Estimation of average treatment effects based on propensity scores. Stata J. 2002;2(4):358-377.

48. Heckman $\mathrm{JJ}$, Ichimura $\mathrm{H}$, Todd P. Matching as an econometric evaluation estimator: Evidence from evaluating a job training programme. Rev Econ Stud. 1997;64(4):605-654. https://doi.org/10.2307/2971733

49. Dehejia R, Wahba S. Propensity score matching methods for nonexperimental causal studies. Rev Econ Stat. 2002;84(1):151-161. https://doi. org/10.1162/003465302317331982

50. Caliendo M, Kopeinig S. Some practical guidance for the implementation of propensity score matching. Discussion paper no. 1588 [document on the Internet]. c2005 [cited 2014 Feb 27]. Available from: http://ftp.iza.org/ dp1588.pdf

51. Rosenbaum PR. Observational studies. New York: Springer; 2002. https://doi. org/10.1007/978-1-4757-3692-2_3

52. Rosenbaum PR. Heterogeneity and causality. Am Stat. 2005;59(2):147-152. https://doi.org/10.1198/000313005X42831

53. Rosenbaum PR. Discussing hidden bias in observational studies. Ann Intern Med 1991;115(11):901-905. https://doi.org/10.7326/0003-4819-115-11-901

54. Cunguara B, Darnhofer I. Assessing the impact of agricultural technologies on household income in rural Mozambique. Food Pol. 2011;36:378-390. https:// doi.org/10.1016/j.foodpol.2011.03.002

55. Ali A, Abdulai $A$. The adoption of genetically modified cotton and poverty reduction in Pakistan. J Agric Econ. 2010;61(1):175-92. https://doi. org/10.1111/j.1477-9552.2009.00227.x

56. Francesconi GN, Heerink N. Ethiopian agricultural cooperatives in an era of global commodity exchange: Does organizational form matter? J Afr Econ. 2011;20:153-177. https://doi.org/10.1093/jae/ejq036

57. Rosenbaum PR, Rubin DB. Constructing control group using a multivariate matched sampling method that incorporates the propensity score. Am Stat. 1985;39:33-38. 